\title{
Notes on Aizoaceae and Chenopodiaceae
}

\author{
S.W.L. Jacobs
}

\begin{abstract}
Jacobs, S.W.L. (National Herbarium of New South Wales, Royal Botanic Gardens, Sydney, Australia 2000) 1988. Notes on Aizoaceae and Chenopodiaceae. Telopea 3(2): 139-143. The new combinations Zaleya galericulata ssp. australis (Melville) S.W.L. Jacobs, Sclerolaena stelligera (F. Muell.) S.W.L. Jacobs and S. brachyptera (F. Muell.) S.W.L. Jacobs are made and Aizoon secundum L.f. (=Galenia secunda) and A. pubescens Ecklon \& Zeyher (= Galenia pubescens) are lectotypified.
\end{abstract}

The following new combinations and lectotypifications are made to make them available for the forthcoming first volume of the 'Flora of New South Wales'.

\section{Aizoaceae}

(i) Zaleya galericulata (Melville) Eichler ssp. australis (Melville) S.W.L. Jacobs, comb. et stat. nov.

BAsIONYM: Trianthema australis Melville, Kew Bull. 7: 266 (1952).

Holotype: New South Wales: Narrabri, White NSW 13559, April 1914 (NSW; dupl. $\mathrm{K})$.

Trianthema australis has either been recognised (Jacobs \& Pickard 1981; Beadle et al. 1982), ignored (Beadle 1972) or treated as a synonym of Zaleya galericulata (Prescott 1984). In none of these publications has there been any discussion of the reasons for its distinction from $T$. galericulata.

Melville (1952) distinguished $T$. australis from $T$. galericulata by:

(a) the 'poorly developed' crest on the apex of the operculum in $T$. australis (well-developed in $T$. galericulata).

(b) stamens 5 (5-12 in T. galericulata).

(c) the reticulate ridging on the side of the operculum (? absent in $T$. galericulata). and

(d) the everted base of the operculum (? not everted in T. galericulata),

(e) the shape of the incomplete septum on the sutural surface of the opercular valves.

A study of the many recent collections in the National Herbarium of New South Wales (NSW) has shown that the range of morphological variation in both $T$. galericulata and $T$. australis is much greater than Melville (1952) supposed it to be. Many of the characters used by Melville to distinguish the two species have been found to intergrade, e.g.: 
(a) the rounded or dome-shaped (as opposed to crested or crowned) operculum supposedly characteristic of $T$. australis is found quite commonly in plants which possess the other characteristics of $T$. galericulata.

(b) a specimen which has other characteristics of $T$. australis has 10 stamens (normally 5).

(c) the distinct reticulate ridges on the operculum, listed as characteristic of $T$. australis are equally common in $T$. galericulata, and

(d) the 'often everted' operculum of $T$. australis is only true in very few cases.

One character, however, does provide a reproducible sorting of the specimens - a sorting in which trends in some other characters and two more or less discrete geographical distributions (Fig. 1) are apparent. That character is the shape of the incomplete septum of the inner articulating faces of the operculum valves (Fig. 2). Melville does mention the septum briefly in his Latin descriptions but, more importantly, provides clear illustrations of the differences between $T$. australis and $T$. galericulata. The character has not subsequently been much used as it is only observable in mature fruit, and describing the differences is difficult. In $T$. australis, the gap between the margins of the incomplete septum of the inner articulating surfaces of the operculum valves is narrowest at the apex and extends almost to the top of the operculum. In $T$.

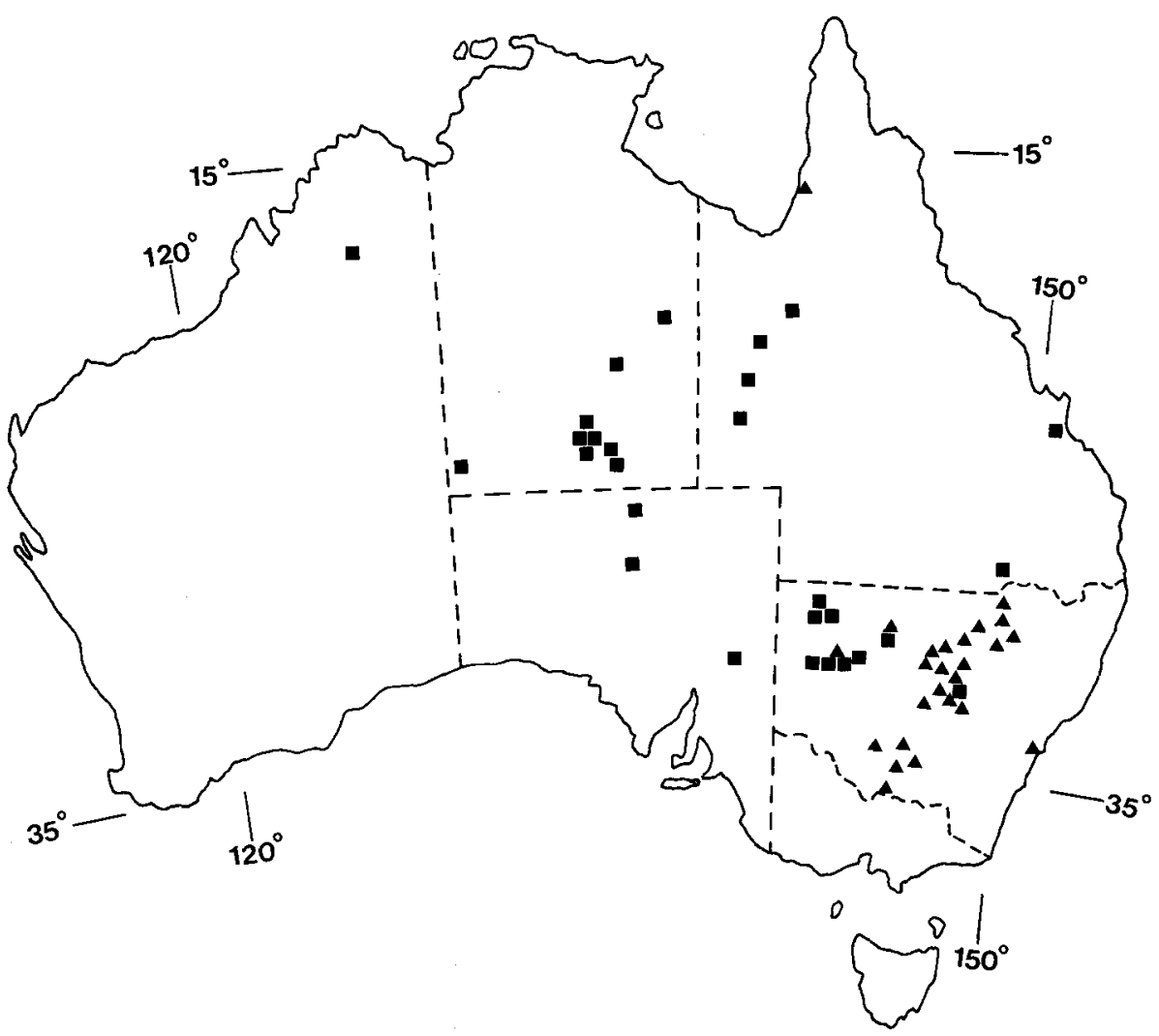

Fig. 1. Distribution of Zaleya galericulata ssp. galericulata (ם) and ssp. australis $(\mathbf{\Delta})$. 


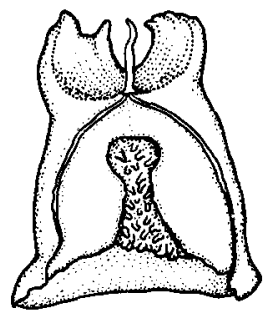

$\mathbf{a}$

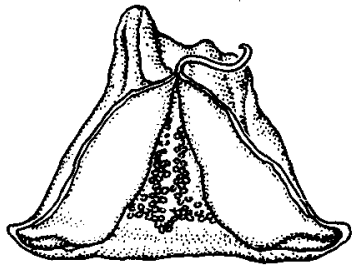

b

Fig. 2. Characteristic shapes of the incomplete septum of the inner articulating faces of the operculum valves in Zaleya galericulata (X10). a, ssp. galericulata (S. Jacobs 3040). b, ssp. australis (Cunningham 1703 \& Milthorpe).

galericulata this gap is narrowest in the lower half of the operculum valves and extends to within about $0.5 \mathrm{~mm}$ of the top of the operculum. Apart from this distinction, $T$. australis mostly has 5 stamens (one specimen at the geographical boundary between the two taxa has 10 stamens), a dome-shaped operculum, and is found mostly on the Western Slopes and Plains of New South Wales, with one specimen from N. Queensland. T. galericulata has 5 or 10 stamens (about half the specimens with each number), the operculum apex is frequently crowned (though this is not developed in many specimens), and is found in the North Far Western Plains (NFWP) of New South Wales and throughout the rest of the mainland States except Victoria, with one specimen from the Central Western Slopes of New South Wales (probably introduced). Both taxa occur in the NFWP of New South Wales, $T$. australis in the SE. of the region and $T$. galericulata in the NW.

In view of the incomplete separation of most of the characters and the discreteness of the geographical distributions, recognition of two subspecies in Zaleya galericulata is the most appropriate treatment.

Jeffrey (1960) treated Zaleya Burm. f. as a genus distinct from Trianthema and transferred two species from this latter genus. He has subsequently been followed in Australia (Eichler 1965, Prescott 1984). The two taxa discussed above, then, become $Z$. galericulata ssp. galericulata and $Z$. galericulata ssp. australis.

(ii) Lectotypification of Aizoon secundum L.f. (=Galenia secunda) and $A$. pubescens Ecklon \& Zeyher (=Galenia pubescens)

The name Galenia secunda (L.f.) Sonder in Harvey [Aizoon secundum L.f.] has been applied to introduced African species differently in New South Wales (Jacobs \& Pickard 1981, Beadle et al. 1982) and in South Australia since Eichler (1965). The earlier treatment in Black (1948) for South Australia agrees with the application of the name in New South Wales. Eichler treated G. secunda sensu NSW and J.M. Black as G. pubescens (Ecklon \& Zeyher) Druce. The application at NSW of the name $G$. secunda was based on identification (and citation, Adamson 1956) of an NSW specimen (NSW 26301 (K, no dupl. at NSW) and the possession of duplicates of some cited African specimens. Prescott (1984) followed Eichler (1965). 
G. pubescens is based on Aizoon pubescens Ecklon \& Zeyher (1837). An isotype (Zeyher 2638, Swartkops River, South Africa) is held at S(!) and, following the convincing arguments of Nordenstam (1980) about the location of the main Ecklon and Zeyher collections, this specimen is here designated as the lectotype of $A$. pubescens.

$G$. secunda is based on $A$. secundum L.f., the Type being a Thunberg collection from 'Cape of Good Hope' s.n. In the Linnean Herbarium in London there is only one Thunberg collection under either Aizoon or Galenia, and this collection is neither labelled nor annotated as $A$. secundum (Savage 1945). This specimen (650.4), even as seen on microfiche, clearly differs from the protologue of $A$. secundum in the shape of the leaves and the degree of hairiness. In Thunberg's herbarium (UPS) there are two specimens labelled $A$. secundum, both from 'Cap. b. spei' (Cape of Good Hope). These specimens represent two different species, one (no. ' 1 ', sheet no. 12058) represents the species referred to as $G$. secunda by Jacobs and Pickard (1981) and treated as $G$. pubescens by Prescott (1984), and the other (no. '4', sheet no. 12059) represents the species treated as $G$. secunda by Prescott. The protologue is so general that it could be equally applicable to either specimen; current usage is no guide since the name has been commonly applied both ways - even Adamson (1956) included specimens of both $G$. secunda and $G$. pubescens (sensu Prescott) within his circumscription of $G$. secunda, even though he recognised $G$. pubescens as a separate species.

Of the characters included in the protologue, the only two that can be used to distinguish the two specimens are (a) degree of hairiness and (b) leaf shape. Although 'hirsuto-canum' could apply to either specimen, sheet no. 12059, with longer hairs, could be regarded as more so. Both specimens also have ovate leaves: specimen 12058 has ovate to spathulate leaves whereas specimen 12059 has ovate to linear-ovate leaves. As the specimen UPS 12059 could arguably be described as a 'better' fit, and its selection as lectotype will require no alteration to the current nomenclature (though it will require some alterations in the application of the name), it is here designated as the lectotype of Aizoon secundum L.f. This preserves the application of the name used in Prescott (1984).

\section{Chenopodiaceae}

\section{(iii) Two new combinations in Chenopodiaceae}

Scott (1978) described the genus Stelligera and resurrected Sclerochlamys F. Muell. Stelligera was separated from Sclerolaena because it possessed both intertepaline and tepaline 'spines'. Sclerochlamys was resurrected without comment but presumably because of the tepaline wing that connects the intertepaline spines. Both genera are monotypic and Wilson (1984) considered them to be closely related both to each other and to species of Sclerolaena, with which they readily hybridize. Both represent extreme forms in Sclerolaena extremes of trends also present in other species (e.g. S. tetragona, $S$. microcarpa, $S$. walkeri). A similar situation occurs with other fruit characters elsewhere in Sclerolaena (e.g. the fimbriate spines of $S$. fimbriolata and $S$. symoniana, and the hollow base and reduction in number of spines in the $S$. uniflora group). There seems little justification for maintaining Stelligera and Sclerochlamys as distinct, and the following new combinations are made: 
Sclerolaena stelligera ( $F$. Muell.) S.W.L. Jacobs, comb. nov.

BASIONYM: Maireana stelligera F. Muell., Fragm. 1: 39 (1859).

TYPE: New South Wales: Salt Plains on the Darling River, J. Dallachy (MEL).

SYNONYM: Stelligera endescaspinis A.J. Scott, Feddes Repert. 89: 115 (1978).

Sclerolaena brachyptera (F. Muell.) S.W.L. Jacobs, comb. nov.

BAsionym: Sclerochlamys brachyptera F. Muell., Trans. \& Proc. Philos. Inst. Victoria 2: 76 (1858).

Lectotype: New South Wales: Salt Flats on Murray River, F. Mueller; see E.H. Ising, Trans. Roy. Soc. South Australia 88: 76 (1964).

\section{Acknowledgements}

I would like to thank Christine Payne for drawing the figures.

\section{References}

Adamson, R.S. (1956) The South African species of Aizoaceae III. Galenia L. J. S. African Bot. 22(3): 87-127.

Beadle, N.C.W. (1972) 'Students Flora of North Eastern New South Wales'. Part 2 (Univ. New England: Armidale).

Beadle, N.C.W., Evans, O.D., \& Carolin, R.C. (1982) 'Flora of the Sydney Region' (A.H. \& A.W. Reed: Sydney).

Black, J.M. (1948) 'Flora of South Australia'. Vol. 2 (Govt Printer: Adelaide).

Eichler, Hj. (1965) 'Supplement to J.M. Black's Flora of South Australia edn 2' (Govt Printer: Adelaide).

Jacobs, S.W.L., \& Pickard, J. (1981) 'Plants of New South Wales' (Govt Printer: Sydney).

Jeffrey, C. (1960) Notes on tropical African Aizoaceae. Kew Bull. 14: 235-238.

Melville, R. (1952) Trianthema pentandra L. and some related species. Kew Bull. 7: 261-269.

Nordenstam, B. (1980) The herbaria of Lehmann and Sonder in Stockholm, with special reference to the Ecklon and Zeyher collection. Taxon 29(2/3): 279-291.

Prescott, A. (1984) Zaleya and Galenia. In A.S. George (ed.), 'Flora of Australia'. Vol. 4 (Austral. Govt Publishing Service: Canberra).

Savage, S. (1945) 'A catalogue of the Linnean Herbarium' (Linnean Soc. of London: London).

Scott, A.J. (1978) A revision of the Camphorosmioideae (Chenopodiaceae). Feddes Repert. Spec. Nov. Regni Veg. 89: 101-119.

Wilson, P.G. (1984) Chenopodiaceae. In A.S. George (ed.), 'Flora of Australia'. Vol. 4 (Austral. Govt Publishing Service: Canberra).

Manuscript received 21 November 1985

Manuscript accepted 15 April 1986 